\title{
The Impact Of Internet On Undergraduates' Study Time
}

\author{
Fadhilat Titilayo Adebisi \\ Fountain University \\ Mass Communication Department \\ Osogbo, Osun, Nigeria
}

\section{Abdul Oluwafisayo}

Saheed 0. Adeyemi Adeyemo

Journalism Department, Lagos State University

Adebola Adegunwa School of Communication,

Ojo, Lagos, Nigeria. (LASUAASOC)

\begin{abstract}
The internet has brought the world to a global village in which one can access almost any kind of information in a blink of an eye. Since the explosion of the Internet in Nigeria and the coming of internet provider coupled with the use of smart phones; schools and colleges have noticed a drop in the amount of study time spent by students. These in some cases have led to poor performance and even a huge dropped out of students in the universities. Kubey et al (2001), showed that $50 \%$ of university students were dismissed for academic failure due to excessive use of the internet. In another survey, 283 undergraduates were considered pathological users as a result of their inordinate use of internet. In this view, this study establishes whether internet use affects study time, by investigating the Internet use pattern of undergraduate students and to determine the impact on their study time. The thrust of the paper is that how much impact has the Internet on the study time of the students and their academic use of internet versus social uses of the internet.
\end{abstract}

\section{BACKGROUND}

Today, the internet has brought the world together and therefore made it a global village in which one can access almost any kind of information in a blink of an eye. In this present age, internet is acknowledged as not only a medium of communication, but recognized as a powerful tool. It is of course one of the major sources of obtaining and retrieving information. Over the decades, computer access and use among undergraduates have grown exponentially. Internet usage among undergraduates encompasses not only its use during the leisure, but also their community involvement and social networks. Balasubramanian and Vidyapeetham (2013) assert that students spend most of their valued time addressing the irrelevances on the internet because of its availability.

Most students use internet for sending emails, chats with friends, use the search engines to obtain information on study guide and materials, research products and services and entertainment. As a consequence, students spend more time online (Balasubramanian and Vidyapeetham, 2013). Over $50 \%$ of youths own more than one e-mail address or display identity, which they use to post private messages to friends or to participate anonymously in online forums, such as chat rooms (Lenhart et al., 2005). It is been discovered in a recent study that students generate fake personalities to penetrate and commit crimes in the world of internet. This is because the internet permits persons to create any image of themselves with 
slim or no social repercussions. It is likely that the time spent on this may reduce time available for personal study.

Okeshola and Adeta (2013) reiterate that information technology revolution accompanying the internet has brought in two edge functions. It has on one hand contributed constructive and productive values to the world. On the other hand, it has fashioned so many maladies that intimidate the order of the society and also producing a new wave of crime to the world. The internet online business services, which typically supposed to be a blessing as it exposes one to a lot of opportunities in various field of life is fast becoming a source of discomfort and worry due to the atrocity being perpetrated through it. The internet as justified by Interpol (during the -Europol 2016 Cybercrime Conference at Singapore) is a fast growing area where crimes are expediently committed. The initiation of the internet has brought about a new turn to various traditional crimes. Criminals on a daily basis are exploiting the speed, anonymity, rapidity, convenience or accessibility of the internet to commit a varied range of criminal activities that know no limits.

In the works of Kraut et al., (1998), it was established that the excessive use of internet is closely related with reduced psychology wellbeing, abridged social support, increased loneliness and depression. Many other researchers have concluded that hours spent on the internet have reduced the students' study time and as well done more harm than good to their assimilative capacity.

Meanwhile, there appear to be many advantages linked with the internet use, there have been a growing concern regarding the risk accompanying the internet overuse. There are ongoing and advanced researches that indicated that undergraduates become addicted to the internet and this in essence bring about Academic failure (Halina et al, 2015). Roberts (2001) states that internet has a significant decrement on students' performance.

- determine hours spends on internet daily by undergraduate students

- examine hours spend studying by undergraduate students

- Investigate whether there is a relationship between hours spends on internet daily and hours spend studying

\section{LITERATURE REVIEW}

Today, the internet has brought the world together and therefore made it a global village in which one can access almost any kind of information in a blink of an eye. In this present age, internet is acknowledged as not only a medium of communication, but recognized as a powerful tool. It is of course one of the major sources of obtaining and retrieving information. Over the decades, computer access and use among undergraduates have grown exponentially. Internet usage among undergraduates encompasses not only its use during the leisure, but also their community involvement and social networks. Balasubramanian and Vidyapeetham (2013) assert that students spend most of their valued time addressing the irrelevances on the internet because of its availability. Individual theory of internet explains how certain characteristics specific to a person influence their likelihood. Internet influences the behaviour of the users. Since internet influences the behaviour of the users, it may have impact on their academic performance. Some empirical reviews support this theory.

Usman, Alavi and Shafeq (2013) identify the relationship between Internet Addiction (IA) and academic performance among foreign undergraduate students in Universiti Teknologi Malaysia (UTM). This study also identified the differences in internet addiction in terms of 
gender and country of origin. Four countries were selected through simple random sampling; there were China, Yemen, Somalia and Indonesia. Then, a total of 120 students were selected randomly from those countries. In order to measure IA, Internet Addiction Test (IAT) based on Young's (1998) survey which modified by Pee and Shafeq (2009), was used. The data collected was analyzed using SPSS. The statistical techniques frequency and percentage were used to identify the patterns of using the Internet; t-test and one-way ANOVA were used to examine the differences in IA in terms of demographic factors. Pearson correlation technique was also used to determine the relationship between IA and academic performance. The results of the study showed that there were no significant differences in IA in terms of gender, country of origin. The results also indicated that there were no significant differences in IA in terms of CGPA. This suggests that future research need to work on large-scale using multiple-campus technology assessments.

Ivwighreghweta and Igere (2016) investigate the impact of the internet on the academic performance of students in some selected tertiary institutions in Nigeria. A survey research design was adopted in conducting this research. Questionnaire was the instrument employed for data collection. Frequency count and simple percentage was used to analyse the data. The study population comprises of six thousand (6000) students, drawn from the University of Benin, Benin City, Delta State University, Abraka, Western Delta University, Oghara and the Delta State polytechnic, Otefe. The study found that majority of the respondents were computer literate and that they make use of the internet, it was discovered that the students frequently access the internet from Cyber Café, and that they consult the internet in order to retrieve relevant academic materials, majority of the students rated the internet for academic pursuit to be on the average, E-journals and E- books were among the resources the students mostly used on the internet. They also indicated that with the help of the internet, they are better prepared for their examinations. It was also revealed that Power outage, slow internet speed, lack of computer terminals, too many hits or information overload, Insufficient computer were some of the problems militating against effective internet access in tertiary institutions in Nigeria. Necessary recommendations were made.

\section{METHODOLOGY}

This section deals with methods adopted for the study. The study is designed as a descriptive survey as it is focused on the relationship between internet usage and undergraduate study time. The population of the study is made up of all undergraduate students of Nigerian universities. The time limit of the study necessitated the need to use only one university. A private university in the South Western Nigeria was selected for the study. 48 undergraduates were conveniently sampled from the total number of students in the University.

A simple questionnaire was designed to elicit information from the respondents. The questionnaire contained 21 items. Three items dealt with personal data of the respondents while the remaining 18 items dealt with issues under investigation. The researchers personally administered the questionnaire to the students in their halls of residence. Frequency counts and percentage were used for the descriptive analysis while Student $t$ test was used to test the hypothesis raised at $5 \%$ level of significance.

\section{DATA ANALYSIS AND DISCUSSION}

This section deals with analysis of data obtained on the survey conducted on the impact of internet on undergraduate study time.

\section{Data Analysis}


Table 1:

Age at First Contact with Internet

\begin{tabular}{|l|c|c|}
\hline Age & Frequency & Percent \\
\hline $5-9$ & 10 & 20.8 \\
$10-14$ & 16 & 33.3 \\
$15-19$ & 17 & 35.4 \\
$20-24$ & 5 & 10.4 \\
Total & 48 & 100.0 \\
\hline
\end{tabular}

The table deals with response on age at first contact with internet. It can be seen that $54.1 \%$ of the respondents agreed that they have their first contact before the age of 14 . This is an indication of many of these respondents may have influenced negatively at early age.

Table 2:

Attraction To Internet

\begin{tabular}{|l|c|c|}
\hline Variable & Frequency & Percent \\
\hline Peer Influence & 3 & 6.3 \\
Social media & 9 & 18.8 \\
Education & 14 & 29.2 \\
Information & & \\
Skill Acquisitions & 1 & 2.1 \\
Entertainment & 15 & 31.3 \\
None & 6 & 12.5 \\
Total & 48 & 100.0 \\
\hline
\end{tabular}

The table shows that entertainment is the most important factor influencing the respondents to internet. $31.3 \%$ of the respondents indicated entertainment (music, movie, sport). 29.2\% and $18.8 \%$ of the respondents indicated education and information, and social media respectively. This shows that entertainment is the main promoter of internet usage among the undergraduate.

Table 3:

Hours Spend Daily On Internet

\begin{tabular}{|c|c|c|}
\hline Hour & Frequency & Percent \\
\hline $1-3$ & 27 & 56.3 \\
$4-6$ & 15 & 31.3 \\
$7-10$ & 6 & 12.5 \\
Total & 48 & 100.0 \\
\hline
\end{tabular}

The respondents were asked to indicate time spend daily surfing the internet. This is just to measure how many hours internet surfing consumed in undergraduates' available study hours. From the table, it can be seen that $43.8 \%$ of the respondents spend more than 4 hours daily on internet surfing. 
Table 4:

Log Time On Internet

\begin{tabular}{|l|c|c|}
\hline \multicolumn{1}{|c|}{ Time } & Frequency & Percent \\
\hline In the Morning & 4 & 8.3 \\
In the Afternoon & 10 & 20.8 \\
At Night & 24 & 50.0 \\
Throughout the Day & 9 & 18.8 \\
Total & 47 & 97.9 \\
Missing System & 1 & 2.1 \\
Total & 48 & 100.0 \\
\hline
\end{tabular}

The respondents identified the time of the day that they log in most to the internet. Table 4.4 shows that it is mainly in the night. $50.0 \%$ of the respondents indicated night time. This shows internet may have consumed night study time of the students.

Table 5:

Favorite Sites on Internet

\begin{tabular}{|l|c|c|}
\hline Favorite Sites & Frequency & Percent \\
\hline Social Media & 37 & 77.1 \\
Commercial & 3 & 6.3 \\
Entertainment & 4 & 8.3 \\
Sport & 3 & 6.3 \\
Crime Buster & 1 & 2.1 \\
Total & 48 & 100.0 \\
\hline
\end{tabular}

The respondents try to indicate their favourite site to identify whether they use internet for academic purpose. Table 5 shows that social media was the favourite site of the undergraduate and it has $77.1 \%$ of the total responses.

Table 6:

Time Consumed by the Preferred Site

\begin{tabular}{|l|c|c|}
\hline Time Consumed & Frequency & Percent \\
\hline 1-3 hour & 32 & 66.7 \\
$3-6$ hour & 12 & 25.0 \\
$7-10$ & 3 & 6.3 \\
Total & 47 & 97.9 \\
Missing System & 1 & 2.1 \\
Total & 48 & 100.0 \\
\hline
\end{tabular}

The finding tends to know proportion of time spend daily on internet that belongs to undergraduates' most preferred site. Table 6 shows that $66.7 \%$ of the respondents spend less than 3 hours daily on their favourite site while 25.0\% spend less than 6 hours on their favourite site. The remaining $6.3 \%$ spend more than 6 hours on their favourite site. 
Table 7:

Hours Spent Studying

\begin{tabular}{|l|c|c|}
\hline \multicolumn{1}{|c|}{ Hours } & Frequency & Percent \\
\hline $0-3$ & 15 & 31.3 \\
$4-6$ & 28 & 58.3 \\
$7-10$ & 4 & 8.3 \\
Total & 47 & 97.9 \\
Missing System & 1 & 2.1 \\
Total & 48 & 100.0 \\
\hline
\end{tabular}

The attempt to know the number of hours students spend on reading every day. $31.3 \%$ of the respondents spend less than 3 hours. 58.3\% of the respondents spend less than 6 hours while the remaining spends more than 6 hours every day.

Hours spent on internet do not have significant impact on undergraduate study time

Table 8:

Test Result

\begin{tabular}{|lll|}
\hline & \multicolumn{1}{c|}{$\begin{array}{c}\text { Hours spent on the } \\
\text { internet }\end{array}$} & $\begin{array}{c}\text { Hours sufficient for daily } \\
\text { study }\end{array}$ \\
\hline Mean & 1.5625 & 1.75 \\
Variance & 0.506648936 & 0.361702128 \\
Observations & 48 & 48 \\
Pearson Correlation & 0.086978335 & \\
Df & 47 & \\
t Stat & -1.457953408 & \\
P(T<=t) one-tail & 0.075751775 & \\
t Critical one-tail & 1.677926722 & \\
\hline
\end{tabular}

Table .8 shows the computation of the relationship between hours spends on internet daily and hours spend studying. The table shows that Pearson correlation coefficient was 0.087 . This was positive but weak. It can be concluded that hours spend surfing the internet has positive weak association with hours spend reading. We therefore concluded that the hours spend on internet has significant impact on hours spend reading at $10 \%$ level of significance.

\section{DISCUSSION OF FINDINGS}

The findings of the study have shown that students spend more than one hour daily surfing the internet. In a university where lectures end by $5 \mathrm{pm}$ daily except on Saturday and Sunday, this may have strong impact on their study time. $48 \%$ of the students surf the internet more than 3 hours daily. This may have been one of the reasons for poor performance of undergraduate students in examination. This is further confirmed by the fact that more than $77.1 \%$ visit social media site daily. This finding is in line with Lekey (2015) who conducted study on internet and academic performance in Bhutan. He found out that students who visited social media sites performed poorly in their academics.

This study in addition showed that social media takes at least one hour of students' hour every day in a university where $89.6 \%$ of the students spend less than 6 hours daily on reading. This shows that the use of internet purposely for social media is detrimental to student reading 
time. If $66.6 \%$ of the students spend more than three hours daily reading and spend $43.8 \%$ spend more than three hours daily surfing their preferred social media site, this shows that surfing internet may have a detrimental effect on students reading time. Though as the hypothesis revealed, this relationship was weak. we therefore conclude like Ngoumandoka (2012) that there was strong association between internet usage and students reading time but there is clear evidence that internet usage has significant impact on students reading time at $10 \%$ level of significance.

\section{CONCLUSION}

The findings of the study showed that internet usage has significant impact on students reading time. In addition, the preferred site of the students is social media which is strictly for social and recreational function. Lastly, hours spent on visiting this social media may have negative impact on their reading time. We therefore recommend that students should take cautioned in exercising in using internet for social media. They should invest their time in maximum reading.

\section{Reference}

Akogwu, S. (2012),An Assessment of the Level of Awareness on Cyber Crime among Internet Users in Ahmadu Bello University, Zaria (Unpublished B.Sc project). Department of Sociology, Ahmadu Bello University, Zaria.

Balasubramaniam, Vidyapeetham (2013). A study on social impact of internet usage on students of state university in Tamil Nadu, India. The Asian Conference on Media and Mass Communication 2013 Official Conference Proceedings Osaka, Japan 8(10), 123-144). Children and computer technology. Los Altos, CA: The David and Lucille Packard Foundation, Journal/Publications Department.

Dorji, L. (2015). The impact of the internet on academic performance of the students at the tertiary level of education in Bhutan. A Dissertation submitted to the Faculty of Management, Royal Institute of Management, in partial fulfillment of the requirements for the Post Graduate Diploma in Public Administration (PGDPA) Lekey Dorji PGDPA Cohort, 2015

Ellore, S. B., Niranjan, S., \& Brown, U. J. (2014). The Influence of Internet Usage on Academic Performance and Face-to-Face Communication. Journal of Psychology and Behavioral Science, 2(2), 163-186.

Folashade B. Okeshola Abimbola K. Adeta (2013). The Nature, Causes and Consequences of Cyber Crime in Tertiary Institutions in Zaria-Kaduna State, Nigeria. American International Journal of Contemporary Research, 3, 9;

Harlina et al (2015). Internet usage and academic performance: A study in a Malaysian Public University. International medical journal, 22(2),83-86.

Ivwighreghweta, O., \& Igere, M. A. (2014). Impact of the internet on academic performance of students in tertiary institutions in Nigeria. Information Impact: Journal of Information and Knowledge Management, 5(2), 47-56.

Kraut, R., Patterson, M., Lundmark, V., Kiesler, S., Mukopadhyay, T., \$ Scherlis, W. (1998). Internet Paradox: A Social Technology that Reduces Social Involvement and Psychological Well-Being? American Psychologist, 53(9), 1017-1031

Kubey RW, Lavin MJ, Barrows R. (2001). Internet use and collegiate academic performance decrements: early findings. J Communicm 366-382.

Lenhart, A., Madden, M., \& Hitlin, P. (2005). Teens and technology: You are leading the transition to a fully wired and mobile nation.

Osunade, O., Ojo, O. M., \& Ahisu, E. V. (2009). The role of internet on the academic performance of students in tertiary institutions. Journal of Educational Research in Africa/Revue en Africanie de recherche en Education (JERA/RARE), 1(1), 30-35.

Shinder, D.L.(2002), Scene of the Cybercrime: Computer Forensics Handbook. Syngress Publishing Inc. 88 Hingham Street, USA.

Usman, N. H., Alavi, M., \& Shafeq, S. M. (2014). Relationship between Internet Addiction and Academic Performance among Foreign Undergraduate Students. Procedia-Social and Behavioral Sciences, 114, 845-851. 